\title{
Fast eller flytende føde etter tarmkirurgi?
}

\author{
Fast føde gir mindre kvalme, kortere liggetid og raskere luftavgang enn \\ flytende kost etter kolorektal kirurgi.
}

Tidligere var man forsiktig med mat etter tarmoperasjoner, men etter hvert er det blitt klart at det er en fordel å introdusere fast føde raskere. Mange starter med ernæring i form av klare væsker, men er dette noe poeng? I en nylig publisert studie har man

undersøkt om fast føde er bedre enn flytende kost etter operasjon.

111 pasienter som skulle gjennom planlagt kolorektal kirurgi, ble randomisert til å få enten klare væsker eller fast føde første dag etter operasjonen. Fra andre dag fikk

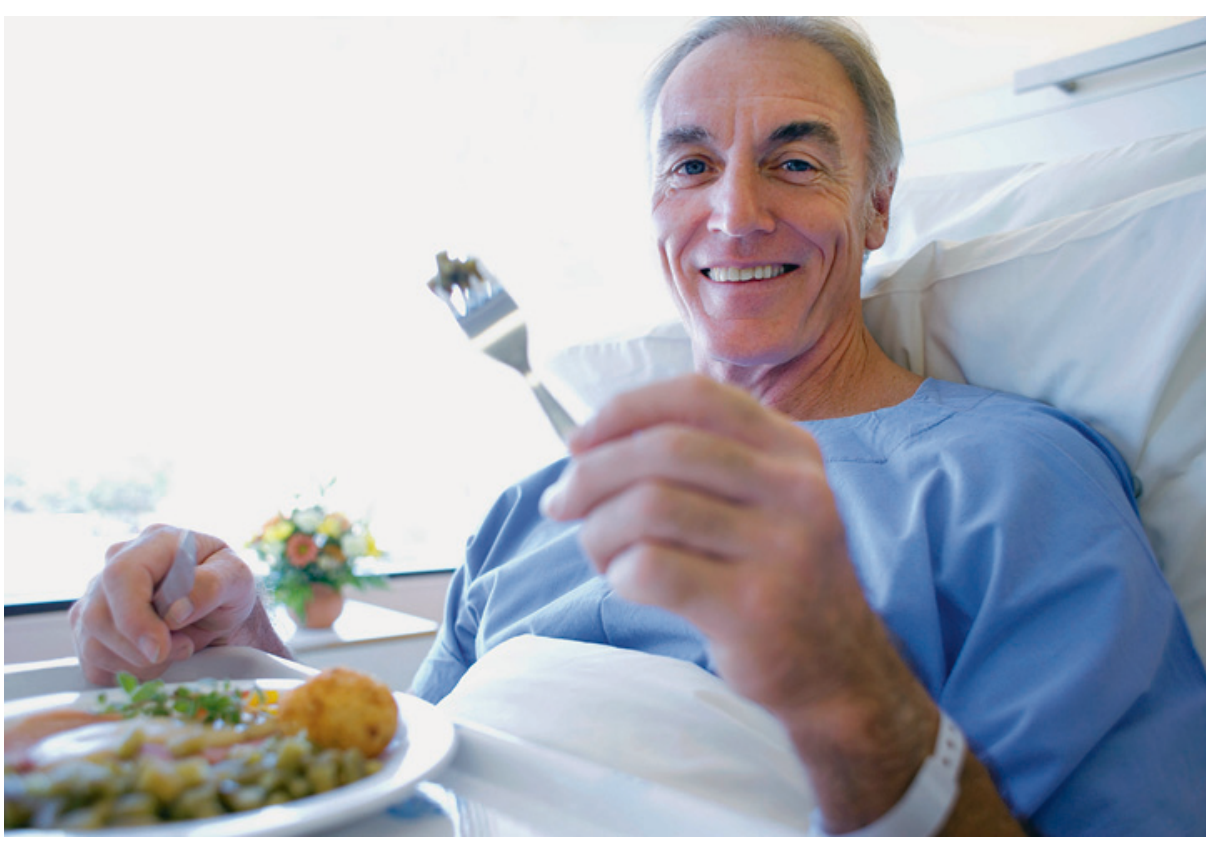

Illustrasjonsfoto: Sciencephoto/NTB scanpix

\section{Mulig nytt prinsipp for smertelindring}

\section{Aldehyder akkumuleres i betent vev og forårsaker smerte. En medi- sin som stimulerer aldehydde- hydrogenase kan kanskje dempe smerten.}

Smerter på grunn av betennelsestilstander er et stort helseproblem. Grunnet en mutasjon i genet for en aldehyddehydrogenase har en tredel av hankinesere lavere smerteterskel enn andre. Kan denne kunnskapen brukes til å utvikle nye medisiner? I en nylig publisert studie fremkalte forskere betennelse i potene til mus og rotter ved injeksjon av prostaglandin $\mathrm{E}_{2}$ eller carrageenan. Deretter målte de smertereaksjonen før og etter at dyrene fikk behandling med en ny medisin (Alda-1) (1).

I de betente potene hopet det seg opp ulike aldehyder, som acetaldehyd og 4-hydro- ksynonenal. Mus med en inaktiverende punktmutasjon i genet for en aldehyddehydrogenase (ALDH2), tilsvarende mutasjonen hos hankinesere, hadde lavere smerteterskel og forlenget opphopning av aldehyder enn mus som ikke hadde mutasjonen. Medikamentet, som forskerne selv hadde laget, aktiverte denne aldehyddehydrogenasen og reduserte aldehydnivåer og smertereaksjoner. Dessuten sank mengden av biomarkøren «early growth response protein 1» (EGR-1), som er forbundet med hyperalgesi, i dyrenes ryggmarg. Medisinen ga ikke mindre hevelse i det betente området.

- Det er spennende at aldehyder ser ut til å spille en viktig rolle for nosisepsjon ved inflammasjon, sier professor Arne Tjølsen, som er del av Nevrovitenskapelig forskningsgruppe og professor ved Institutt for biomedisin, Universitetet i Bergen. - Hvis man kan redusere konsentrasjonen av aldehyder, vil det åpenbart være et mulig alle fast føde. Det var ingen signifikant forskjell mellom gruppene når det gjaldt oppkast etter to dager. Gruppen som fikk klare væsker, var mer plaget med kvalme under sykehusoppholdet enn gruppen som fikk fast føde fra første dag. Det tok lengre tid før gruppen med flytende kost fikk luftavgang (4,8 dager versus 3,7 dager, $p=0,04)$, og de lå gjennomsnittlig lenger på sykehuset $(7,0$ dager versus $5,0, \mathrm{p}=0,01)$. Det var ingen forskjell i postoperativ morbiditet mellom gruppene.

- Jeg er skeptisk til denne studien - om pasienter kan få vanlig mat direkte etter kolorektal reseksjon fremstilles som et reelt forskningsspørsmål, sier Kristoffer Lassen, som er overlege ved Avdeling for gastroenterologisk kirurgi ved Universitetssykehuset Nord-Norge. - Dette er et utdatert og oppkonstruert spørsmål å undersøke. Dagens litteratur på feltet tilsier at det er en klar fordel med fast føde raskt etter operasjon, sier han.

- Det er vanskelig å innføre nye kunnskapsbaserte rutiner i daglig praksis, men det er ikke noe man trenger å bruke en randomisert undersøkelse til å belyse. Denne studien tilfører ikke noe nytt for det norske kolorektalkirurgiske miljøet, sier Lassen.

\section{Lise Mørkved Helsingen \\ Tidsskriftet}

\section{Litteratur}

1. Lau C. Phillips E, Bresee $C$ et al. Early use of low residue diet is superior to clear liquid diet after elective colorectal surgery: a randomized controlled trial. Ann Surg 2014; 260: 641-9.

angrepspunkt for en ny type smertedempende midler, sier han.

- Reduksjon av EGR-1 (også kalt Zif268) i ryggmargen taler for at medikamentet reduserer aktiviteten i perifere nosiseptorer, ikke i mer sentrale nevroner. Denne reduksjonen av signaltrafikk kan motvirke sensitivisering i sentralnervesystemet. Det blir svært interessant å følge veien mot medikamenter som kan prøves ut på mennesker. Vi kan håpe at dette kan gi flere og bedre muligheter for å lindre smerte ved inflammasjon, sier Tjølsen.

\section{Haakon B. Benestad}

Universitetet i Oslo

\section{Litteratur}

1. Zambelli VO, Gross ER, Chen $\mathrm{CH}$ et al. Aldehyde dehydrogenase-2 regulates nociception in rodent models of acute inflammatory pain. Sci Transl Med 2014; 6: ra118. 